\title{
Operation of Public Service Quality in Governmental Lanjas Village, District of North Barito
}

Halen Perdana*, Jamaluddin, Budi Suryadi

Master Program of Government Science, Lambung Mangkurat University, Banjarmasin, Indonesia

DOI: $10.36348 /$ sijlcj.2019.v02i11.004

| Received: 08.11.2019 | Accepted: 15.11.2019 | Published: 19.11.2019

*Corresponding author: Halen Perdana

Abstract

Public service is the main task of the government as a public servant, without exception the village office. The district office serves as the first service to the community. Therefore the quality of service is needed in providing services to the public. Research methods used in this research is qualitative descriptive methods and techniques of collecting data through observation and in-depth interview to the informant. Informants in this study are three (3) key informant namely Lanjas Village and village officials, as well as the Community. Based on the results showed that the implementation of quality public services at the village administration Lanjas quality is still not due to budget constraints, inadequate infrastructure, the number of employees who are still lacking and awareness for the qualified in service. Expected to increase the budget as well as the urban infrastructure facilities, as well as additional staff to provide a quality service to the community.

Keywords: Quality Public Services, Government Village.

Copyright @ 2019: This is an open-access article distributed under the terms of the Creative Commons Attribution license which permits unrestricted use, distribution, and reproduction in any medium for non-commercial use (NonCommercial, or CC-BY-NC) provided the original author and source are credited.

\section{INTRODUCTION}

Public services and public services is an allocation of resources through political mechanisms rather than through the market, the quality of service depends heavily on the quality of democracy [1]. The consequence of this case is the state that the pillars of democracy do not work optimally and do not allow the achievement of quality public services better. Instead, public services without the democratic political process tend to open up space for corrupt practices. As part of the state system with a dense constitution with the norms of justice, the Indonesian economy is characterized by the scope of public services is extensive. Public services in Indonesia have a characteristic that tends to corrupt, especially about the procurement of products that are public service obligations such as Identity Card (KTP).

In the context of public service in the simpler case is the formation of village organizations as a special institution in charge of providing direct services to the public. Be regarded as government management in the area. That is, the formation of this organization is empirically has produced results in the form of increased productivity quantitatively minimal public services. Context theory Reinventing Government, the establishment of the village live the meaning of community-owned, mission-driven, result-oriented, customer-oriented, and anticipatory government [2]. Therefore, the Village Office developed management practices at the regional level at the lowest level. One opportunity is developed is the provision of services of higher quality service, fast and accurately, and supported by an adequate budget. It is expected that public services at the village level can run as expected.

However, services in the village are still found people are not being served. The fact was caused only because of geographical factors as well as by some of the requirements specified. These services should not be the responsibility of the waiter but also of the party requesting the service to improve the quality of service to customers. The fact is caused by a variety of obstacles that led to public discontent. Public services are organized by public bureaucracy. The community of users faced with the uncertainty of bureaucracy. Village Office's empirical existence has managed to boost public services. However, it is understood that the service of a letter of introduction, fiber and other administrative information. Village Office indirectly serves as a 'counter' receiver continued application process to the Department/Institution respective functional. In such conditions, the village office it may be perceived as 'The Door Leading Bureaucracy' in 
service to the community. This article aims to describe the public services that occurred in the Village of North Barito regency Lanjas. To get a description of whether public services have been met

\section{RESEARCH METHODS}

This study is a descriptive study with a qualitative approach. Qualitative research is a research procedure that produces descriptive data in the form of words written or spoken of people and observed behavior. Descriptive research is a form of study aimed to describe or depict phenomena, both natural phenomena and human engineering [3, 4]. The purpose of descriptive research is to make systematic, factual, and accurate about the facts and the nature of the population or a particular region. Research focuses on aspects of the implementation of public services. Informants of North Barito regency society concerned with the Village Office and officers who hold the key (key informant) in the research area,

Data collection techniques include; 1) observation of participation, in which researchers directly involved with the daily activities of people who are being observed or used as a source of research data, 2) structured interviews in order to focus and focus on the intended purposes and avoid talking too wide, 3) documentation to dig Data in the form of photographs of the condition of service activities and other services. Data analysis techniques by Miles and Huberman with three grooves of activity, namely data reduction, data presentation, and drawing conclusions or verification [5]. The mechanical validity of data used triangulation techniques [4]. Triangulation is a testing technique to verify, change-expanding information from one to another principal offender or of the perpetrator until saturated.

\section{RESULTS AND PEMBAHASANA Quality Public Services in Sub Lanjas}

The quality of public services in an effort to fulfill everything related to production, services, people, processes, environments, and the needs and desires of consumers. Quality of service generally must meet customer expectations and satisfy the needs. Quality of public service delivery agencies that administer the duty of care, especially in government agencies. This village government agency which is the entrance to the service of the bureaucracy [6]. Therefore, the quality of service is not an obligation for the village government to provide quality service to the community. To determine whether or not the quality of service at the Village government Lanjas views of some proposed criteria of quality or not.

The first dimension is the dimension to be considered Tangible (physical appearance). On the dimension of some indicators such assessments; The location and the office parking lot, room service and the reception area of services, tools and support tools as well as the appearance of employee services. All indicators assessment on the Tangible dimension, filled with good. The first location of the office, village office locations Lanjas certainly has very easy access as it is located within the city and is not far from the district office. Therefore, every citizen/community has an interest easy to come to the village office. Similarly, parking lot.

However, there are no available parking attendants who set the position of the vehicle. Then for the nonsmoking room service and service reception area, this indicator is slightly less than satisfactory because there is no special room. Besides, there is no place, in the office this hot condition caused by a lack of air conditioning facilities so that any customer convenience cannot be catered for. Another indicator of this is the dimension Tangible tools and service support tools are highly related to facility services such as Computers, Printers, Ac. Indicators have not been up for tools such as computers and printers are very less as there are only four computers and three printers.

The second dimension is the dimension Reliability (reliability) of this dimension concerning the accuracy of services and the ability of employees to use the tools in the service. Service Accuracy is the accuracy in the good service in making a cover letter, a certificate requested by the community [7]. The indicators in this criterion are the lack of precision in the service of the error made by village officials to provide services. In terms of providing information, the information in question is not only of village officials, but also the information asked of the community by village officials and in the process of making public the documents requested.

Accuracy of service shown by the village government has been very good, although sometimes there are small errors that occur, such as an error writing the name, place of birth date of the applicant and address of the applicant. Errors also occur not only from the internal village officials but also from external factors such as public service users themselves who err in providing complete requirements. Other external error also becomes an obstacle which the letter issued by the village sometimes rejected or required to be fixed by the agency continued despite the letter format has become the standard format in lanjas village government and has often been given to the public. In certain agencies require the addition of any format or sentence and stuffing that makes people have to go back to the village office to fix it [8]. Then concerning the ability of employees to use the tools already excellent services for all urban employees to operate the equipment properly in the service process.

The third dimension is the dimension Responsiveness (responsiveness) in this dimension there are several indicators used in assessing the quality 
of public service delivery in urban lanjas as a response to end-users and perform services quickly. In this dimension described in the research that all employees of the village responds well to any users of the service who came and also to speed the service process was practically no problem even though there is a delay was not caused by faulty district staff but because of their limited service facilities as well as the number of employees who serve the users of these services [9].

The fourth dimension is the dimension Assurance (guarantee) it involves a guarantee on service time associated with waiting for time and process required community service as a user of the service [10]. In this dimension, the public service of the government has been a good village. Although sometimes the service takes longer and people are made to wait longer to be served. This is because not all types of services can be completed at the same time since each type of service has different requirements and processes. Making the cover letter marriage takes longer than the maintenance certificate and a certificate of business cannot afford. Another factor causing the process and wait time becomes longer society is the number of people to be served while the apparatus that serves unlimited power. Therefore, the people who came had to queue to be served well. Another factor is the conditions of service are incomplete be other factors that hamper the timeliness of service.

The fifth dimension is the dimension Empathy (empathy) Assessment of quality public is going according to the expectations of society in this dimension among others put the interests of service users, employees serve with courtesy, the employee serves with non-discriminatory, and officers serve and respect each user service [9]. But in practice, they are not run as expected indicators such as community service employees have not served with a friendly attitude. There are still some users of the service that has not to smile and greeting to users of the service in the service. Still perceived by users of the service who get inhospitable service employees. Service users are not satisfied if the employee does not give hospitality to service users who perform the service process.

One of the main factors of success in ministry is the friendliness of the service users which one example to smile and say hello, with a smile and greeting the service users feel that they have observed and from it emerges from the hearts of users of services that service users feel comfortable with the services provided by the service provider. Friendliness is not an asset, but the hospitality is the key to success for service providers to establish a good relationship with the users of the service.

\section{Implementation Constraints Factor Quality Public Services In Sub Lanjas Budget limitations}

Every institution is certainly a very important budget to be met following the needs required by the agency, especially in government agencies such as the wards. Factor budget to one factor that becomes obstacles for village lanjas quality service delivery because lanjas village budget only amounted Rp 50.000 .000 , - in one budget year. This budget certainly is still lacking, considering the service provided to the public very much. Therefore, with such a small budget would not be able to maximally provide a quality service to the community.

\section{Facilities and infrastructure}

Further limiting factor is Infrastructures owned by the Village Office Lanjas. It can be seen from the lack of supporting facilities such as computer services, convenient service room, lounge area that is convenient for users of the service. The availability of computers at the existing printer in the village office is very less because there are only 4 computers and 4 printers are used by 10 employees in providing services to the community. It certainly almost in providing quality services due to the lack of this means the time required becomes longer in service because they have to take turns to use the computer. Then the other constraint is the lack of room service and a comfortable lounge area. This is because the district office did not have air conditioning and is still using fans and even then some rooms do not have a fan. This certainly reduces convenience for employees and the community. The fan would interfere with services due to the files easily scattered due to the fan.

\section{Availability Employee / Apparatus}

Budget constraints and infrastructure is the availability of an employee. Where the 10 employees in the village office it is still lacking in providing services for the number of people that much. This is evidenced by the absence of employees who will typically be in the service section as well as an information center for the community. Each section has only two employees first section heads and one staff. Thereby necessitating a section head still providing services in the manufacture of correspondence that should be done by the staff.

\section{Citizen's awareness}

The factor that is important and it will be an obstacle if not addressed is public awareness. This is to comply with the rules of public awareness villages as well as in meeting the requirements for each type of service. This is evidenced still find people who have not been able to attach conditions, such as an introduction to RT and do not carry Copy of ID as a basic requirement for each type of service. 


\section{CONCLUSION}

Service is the main task of the essentials of the figure of the apparatus, as civil servants and public servants. The scope of services and public services (public services) covering aspects of community life is very broad. Concerning the implementation of quality public service at the Village Government Lanjas Barito Utara rating of five. The dimensions of quality of public services. Three of the five dimensions generally complied with and implemented, namely; Responsiveness dimension (Response), Assurance (Security), and Empathy (Empathy). However, the dimensions Tangible (physical appearance) and Reliability (reliability) have not been filled up, especially the facilities and infrastructures. Therefore, said public service delivery in urban quality lanjas yet. Limiting factor in the quality of public service at the Village Office Lanjas is about budget limitations. Lack of Facilities and Infrastructure, availability of employees and community awareness. The Village can provide the best service as well as the completeness of facilities and infrastructure supporting such services; $\mathrm{AC}$, so it does not use a fan. It also interferes with the conditions of service as offices and other facilities (computer and printer). Extra power apparatus in which the population of many villages. With these constraints to be addressed then it is very likely the village office can provide maximum service.

\section{REFERENCES}

1. Beratha, N. (1982). Desa, Publik, Konsep, Teori dan Aplikasi. Yogyakarta: Pustaka Pelajar.

2. Agustino, L. (2008). Dasar-Dasar Kebijakan Publik. Bandung: Alfabeta.

3. Bungin, B. (2008). Analisis Data Penelitian Kualitatif. Jakarta: Raja Grafindo Persada.

4. Ibrahim. (2015). Metode Penelitian Kualitatif. Bandung: Alfabeta.

5. Moleong, L. J. (2004). Metodologi Penelitian Kualitatif. Bandung: Remaja. Rosdakarya.

6. Lukman, S. (2011). Manajemen Kualitas Pelayanan. Jakarta: STIA LAN Press.

7. Moenir. (2006). Manajemen Pelayanan Umum di Indonesia. Jakarta: PT. Bumi. Aksara.

8. Winarsih, A. S. (2007). Manajemen Pelayanan. Yogyakarta: Pustaka Pelajar.

9. Hardiansyah. (2011). Kualitas Pelayanan Publik. Yogyakarta: Gaya Media.

10. Dwiyanto, A. (2010). Manajemen Pelayanan Publik: Peduli, Inklusif, dan. Kolaboratif. Yogyakarta: Gadjah Mada University Press. 